Biol. Neonate 1976;28:I-IV

\title{
Contents, Vol. 28, 1976
}

\section{Contents}

Sokal, M. and Sinclair, J.: Effect of Temperature on Growth of Newborn Rabbits ... 1 Wong, M.D.; Thomson, M.J., and Burton, A.F.: Metabolism of Natural and Synthetic Corticosteroids in Relation to their Effects on Mouse Fetuses 12

Ogawa, Y.; Okamoto, T.; Fukuda, M.; Hirataní, Y., and Ogawa, J.: Estimation of Surfactant Lecithin in Amniotic Fluid and Prediction on Respiratory Distress Syndrome 18

Liu, D.K.; McKee, E.E., and Fritz, P.J.: Transfer RNA and Aminoacyl Transfer RNA in Developing Rats 27

Mydlil, V.; Tomásová, H.; Cápová, E., and Cerná, M.: Acetylcholinesterase Activity in the Erythrocytes of Newborn Infants with Hyperbilirubinemia and Asphyxia . . 36 Sulyok, E.; Jéquier, E., and Prod'horn, L.S.: Relationship between Body Size, Thermal Balance and Thermal Insulation of Term Infants under Various Ambient Con ditions 42

Phelps, D.L.; Omori, K., and Oh, W.: PAH Clearance, Sodium Excretion, and PAH Extraction Ratio in Acidotic Near-Term Lambs Treated with Hypertonic Sodium Bicarbonate 57

Kaplay, S.S.: Acetylcholinesterase and Butyrylcholinesterase of Developing Human Brain 65

Randall, G.C.B. and L'Ecuyer, C: Tissue Glycogen and Blood Glucose and Fructose Levels in the Pig Fetus during the Second Half of Gestation 74

Papiha, S.S. and Burn, J.: Isoelectric Focusing of Non-Specific Esterases of Developing Human Brain in Thin-Layer Polyacrylamide Gels 83

Bocek, R.M.; Young, M.K., and Beatty, C.H.: Cyclic AMP in Developing Muscle of the Rhesus Monkey: Effect of Prostaglanding E2 92

Hrodek, O.; Mydlil, V.; Housková, J., and Veliskovå, V.: Fibrinolysis, Fibrinogen and Thrombin Time in Newborns 106

Agar, N.S. and Harley, J.D.: In vitro Metabolism of Red Blood Cells from Newborn and Adult Goats 113

Larroche, J. C.: Histological Sturcture of the Thyroid Gland in the Newborn. With Special Reference to Hypotrophy, Hydrops fetalis and Cesarean Section Delivery . 118 Papalia-Early, A. and Gruenwald, P.: The Villous Stems of the Human Placenta .... 125 Beaudoin, A.R.: Effect of Adenosine Triphosphate and Adenosine Diphosphate on the Teratogenic Action of Trypan Blue in Rats 133 Lynch, A.; Dobbing, J.; Adlard, B.P.F., and Smart, J.L.: Effects of Early Postnatal X-Irradiation on the Cerebellum Correlated with Adult Motor Performance in Rats 140 
Rautenbach, M. and Beyreiss, K.: Turnover Rates of Fructose and Their Influence on Glucose Blood Level in Preterm and Term Newborns Appropriate for Gestational-Age in Comparison with Preterm and Term Small-for-Gestational-Age Infants . . 153

Contents

IV

Wamberg, S.; Kildeberg, P., and Engel, K.: Balance of Net Base in the Rat. I. A Technical Approach 160

Wamberg, S.; Kildeberg, P., and Engel, K.: Balance of Net Base in the Rat. II. Refer ence Values in Relation to Growth Rate 171

Alexiou, D.; Grimanis, A.P.; Grimani, M.; Papaevangelou, G., and Papadatos, C: Con centrations of Zinc, Cobalt, Bromine, Rubidium and Gold in Maternal and Cord Blood Serum 191

Vasan, N.S. and Chase, H.P.: Brain Glycosaminoglycans (Mucopolysaccharides)

Following Intrauterine Growth Retardation 196

Garel, J.-M.; Savajol, H, and Barlet, J.-P.: Plasma Immunoreactive Calcitonin Levels in Pregnant Ewes and Their Lambs 207

Bard, H: Postnatal Synthesis of Adult and Fetal Hemoglobin in Infants with Con genital Cyanotic Heart Disease 219

Ricquier, D. and Hemon, P.: A Study of Phospholipids and Triglycerides in Several Tissues of the Rat during Fetal and Neonatal Development. Effect of Cretinism . 225 Hemon, P.: Some Aspects of Rat Metabolism in the Brown Adipose Tissue of Normal and Hypo thyroid Rats during Early Postnatal Development 241

Göbel, U. and Petrich, C.: Position of the Oxygen Dissociation Curve in Newborn with ABO Constellation between Mother and Child 256

Widdowson, E.M. and Crabb, D.E.: Changes in the Organs of Pigs in Response to Feeding for the First $24 \mathrm{~h}$ after Birth. I. The Internal Organs and Muscles 261

Widdowson, E.M.; Colombo, V.E., and Artavanis, C.A.: Changes in the Organs of Pigs in Response to Feeding for the First $24 \mathrm{~h}$ after Birth. II. The Digestive Tract . . 272

Knopp, J. and Fáberová, A.: Ontogenetic Development of Deiodinase and Aminotransaminase in Rat Thyroid Gland 282

Vaisman, S.L.; Lee, K-s., and Gartner, L.M.: Diminished Enhancement of Hepatic UDP Glucuronyl Transferase (Bilirubin) by Phenobarbital during Pregnancy in the Rat 287 Voglino, G.F. and Ponzone, A.: 3/4-Microglobulin in Colostral Secretions 297 Mestyán, I.; Horváth, M., and Mestyån, J.: Plasma Osmolality in the Early and Late Neonatal Period with Particular Reference to Low Birth Weight Infants 303 Marsac, C; Saudubray, J.M.; Moncion, A., and Leroux, J.P.: Development of Gluconeogenic Enzymes in the Liver of Human Newborns 317

Parvez, H; Gripois, D., and Parvez, S.: Corticosteroid Influence in the Postnatal Development of Monoamine Oxidase Activity in the Young Rats 326 Effiong, C.E.; Taiwo, O.; Odeniyi, O.O. , and Mellits, E.D.: Haematological Values in Healthy Full-Term Nigerian Newborn Infants 336

Stave, U. and Armstrong, M.D.: Free Amino Acids in Newborn and Adult Rabbit Liver after Prolonged Hypoxia 347

Dahlquist, G. and Persson, B.: Effect of Intrauterine Growth Retardation on the Postnatal Development of $Z>-\beta$-Hydroxybutyrate Dehydrogenase Activity in Rat Brain. 353

Misra, U.K. and Srivastava, N.: Vitamin A and Liver Lipids of Suckling Rats 365 
Meloni, T.; Costa, S., and Cutillo, S.: Three Years Experience in Preventing Severe Hyperbilirubinemia in Newborn Infants with Erythrocyte G-6-PD Deficiency . . 370 Thompson, G.E. and Bell, A. W.: Heat Production in the Newborn Ox during Noradrenaline Infusion 375

Book Review 260

Author Index 382

Subject Index 383 